\title{
Effects of tributyltin chloride on cell structures of epithelial layer in different stages of Artemia salina (Linnaeus, 1758)
}

\author{
Najla Mohamed Abushaala* \\ Zoology Department, Faculty of Science, University of Tripoli, Tripoli, Libya
}

\begin{abstract}
Background: Tributylin chloride (TBTCl) has been demonstrated to be acutely toxic to aquatic organisms.

Aim: This study was conducted to investigate the effects of TBTCl on epithelial cell of gut Artemia salina in different stages (Nauplii, Juveniles, and Adults).

Methods: Samples of $A$. salina used were cultivated in incubators for hatching. Nauplii were harvested at 24 hours of age, while the juveniles and adults were harvested at 21 and 35 days of age, respectively. These three stages of $A$. salina were exposed to different concentrations of TBTCl $\left(1 \mathrm{ng} . \mathrm{L}^{-1}\right.$ to $\left.500 \mathrm{ng} . \mathrm{L}^{-1}\right)$ for 24 hours. For nauplii, juveniles, and adults, 100 individuals were exposed, and those that survived in the exposure test were harvested for histological analysis.

Results: The histological examinations revealed significant differences $(p<0.05)$ in type of lesions associated with different $\mathrm{TBTCl}$ concentrations and at different stages. The predominant lesions associated with different stages and different concentrations of TBTCl were epithelial cell necroasis, degeneration, cell loss, disruption, piknosis, and submucosal necrosis. Cell scoring was a significant difference $(p<0.05)$ between the groups of different TBTCl concentrations and different life stages.

Conclusion: Overall, in this study, the generality of the lesion scores showed that the adults are relatively more susceptible to the effects of TBTCl compared to the juvenile and the nauplii.

Keywords: Antifouling biocides, Artemia salina, Histology, Toxicity, Tributyltin chloride.
\end{abstract}

\section{Introduction}

Tributyltin (TBT) has been demonstrated to be acutely toxic to aquatic organisms and associated with reproductive impairments in both snails and oysters (Abushaala et al., 2015; Gibbs et al., 1988; Li et al., 2015). On the other hand, tributylin chloride (TBTCl) has been shown to have both high fungicidal and bactericidal properties. It is widely admitted that triorganotins and most specifically TBTs are probably the more toxic compounds ever deliberately introduced into the marine environment. These organotins are extensively utilized in wood preservation, for disinfecting circulating industrial cooling waters, and in marine antifouling paints (Costa et al., 2013; Mee and Fowler, 1991). A careful examination of studies that have reported the toxicities of TBTCl in water and in different species revealed very large in acute response (Gallo and Tosti, 2015; Meador, 1997; Zuo et al., 2014).

The effects of TBTCl on different tissues and cells of diverse animal species in the aquatic environments have been established in several related studies (Abushaala et al., 2015; Costa et al., 2013; Gallo and Tosti, 2015). The study of the internal part of marine crustaceans was conducted much earlier, for example, by Couch (1977), who investigated the effect of TBTCl on the gills of the marine shrimp, Penaeus duorarum, and later Griffiths (1980) reported the effects of TBTCl on the gut diverticula of Daphnia magna. Besides that Papathanassiou and King (1986) investigated the effects of TBTCl on the gills and hepatopancreas of the prawn Palaemon serratus, while Papathanassiou and King (1986) reported the effects of TBTCl on the gill cells of the brown shrimp, Crangon crangon. Later, Soegianto et al. (1999) investigated the effect of TBTCl on the epithelial cells of gills, hepatopancreas, and epipodites of the late juveniles of Penaeus japonicas, while Wu et al. (2009) reported the effects of TBTCl on the gills of a white shrimp, Litopenaeus vannamei. Collectively, these studies suggested that TBTCl concentrations altered the cell organelles of aquatic organisms especially of crustacean (Gallo and Tosti, 2015; Li et al., 2015; Mitra et al., 2015).

Studies using brine shrimp Artemia salina were mostly addressing different types of pollutants and as a model of acute toxicity to TBTCl and other compounds (Nunes et al., 2006; Panagoula et al., 2002). Very limited information on histopathological effects of TBTCl on A. salina but numerous studies were conducted on other types of pollutants in other marine crustacean as example studies on the effect of mercury on the gill and hepatopancreas of the prawn, Macrobrachium malolmsonii (Pack et al., 2014; Yamuna et al., 2009), and the effects of sublethal concentrations of zinc 
and cadmium on the hepatopancreas cells of the terrestrial isopod, Porcellioscaber (Žnidaršič et al., 2003). Petroleum hydrocarbons at high sublethal concentrations have been shown to cause intense damage to the hepatopancreas cells (B-cells) of the penaeid shrimp, Metapenaeus dobsoni (Sreeram and Menon, 2005). Mixtures of heavy metals have been demonstrated to have a similar impact on the gills, hepatopancreas, and epipodites of juveniles white shrimp, Litopenaeus vannamei (Frías-Espericueta et al., 2008). In aquatic environments, the risk of TBTCl toxicity is considered greater for marine and freshwater organisms (Ranilalitha et al., 2014). In marine water species, TBTCl has the ability to accumulate in the bodies of crustaceans and fish than in ambient water and subsequently transferred to the food chain (Cuypers et al., 2010; Peranandam et al., 2013; Ranilalitha et al., 2014). Therefore, a greater understanding of the sublethal effects of TBTCl on marine water crustacean species is a high priority for research. Hence, the aim of this research was to investigate the effects of different concentrations of TBTCl on the epithelium layer in the gut of these three different stages of a model species brine shrimps $A$. salina.

\section{Materials and Methods}

\section{Test organisms}

The A. salina was hatched and cultured in the Ecotoxicology Laboratory Department of Biology, Faculty of Science, Universiti Putra Malaysia. They were placed on $600 \mathrm{~mm}$ plastic aquarium with artificial seawater of $35 \pm 1 \%$, $\mathrm{pH}$ at $8 \pm 0.5$, and temperature at $28^{\circ} \mathrm{C} \pm 1{ }^{\circ} \mathrm{C}$ with continuous aeration. The photoperiod cycle was 12 hours light and 12 hours dark. The $A$. salina was fed with marine microalgae commercially produced Tetraslimis sp (Abushaala et al., 2015; 2017).

\section{Reference toxicant}

Tributyltin chloride ( $\mathrm{TBTCl}-\mathrm{C}_{12} \mathrm{H}_{27} \mathrm{ClSn}$ ) was purchased from Sigma-Aldrich (USA; 96\% purity). The preparation of TBTCl stock $(1 \mathrm{mg} / \mathrm{L})$ was made using artificial seawater and Instant Ocean®; Aquarium Systems, Sarrebourg, France at $35 \pm 1 \%$ with aeration and stabilization for 24 hours. After that, the appropriate different concentrations of TBTCl were made using artificial seawater (Abushaala et al., 2015; 2017).

\section{Experimental design}

The samples of $A$. salina were acclimatized to laboratory conditions ( 24 hours for nauplii, 21 days for juveniles, and 35 days for adults stage) prior to being exposed to different concentrations of TBTCl. The test was carried out in small Petri dishes, and 10 individuals of A. salina were transferred with a Pasteur pipette into each Petri dish in five replicates for each concentration. The general range of concentrations of TBTCl dilutions was $1,25,50,100,150,200,250,300,350,400$, 450, 500 ng. $\mathrm{L}^{-1}$ for all different stages of $A$. salina to different stages (nauplii, juveniles, and adult stage), In two groups (Set A \& Set B), A. salina was placed in the Petri dishes (10 individuals in each dish) with 10 $\mathrm{ml}$ of TBTCl at different concentrations. All the Petri dishes were covered to avoid evaporation, and constant aeration was supplied via a glass pipette for 24 hours exposure to TBTCl. The survivors were used to study the effect of toxicant on the histological changes. The experiment was conducted in fully artificial seawater (Abushaala et al., 2015; 2017).

\section{Histological observation and analysis}

The TBTCl had an effect on the A. salina tissue in different stages exposed to the acute different concentrations. After exposing individuals from different stages to corresponding concentrations of TBTCl for 24 hours, the mortality rate was recorded and those that survived were used for histological studies. After 24 hours of exposure, we observed that some nauplii, juveniles, and adults still survived but they were not as active as the normal ones. The histopathological result showed several lesions on the tissues of nauplii, juveniles, and adult stages after exposed to TBTCl. Dissection was performed under a light microscope (Wild Haardage) by a fine needle and forceps. Samples for light microscopy were fixed in Bouin's solution for 24 hours and rinsed in several changes of $70 \%$ alcohol to remove picric acid. Prior to dehydration, prestaining hematoxylin was used for nauplii stage for 10 minutes, subsequently dehydrated in a series of ethanol from $80 \%$ to $100 \%$. The tissues were then cleared in xylene prior to embedding in paraffin wax. Finally, serial sections of $5 \mu \mathrm{m}$ thickness were cut by microtome (AS 325, Shandon) and stained with hematoxylin and eosin (H\&E).

\section{Data analysis}

The statistical analysis for histological study after observed acute toxicity effects of TBTCl on cell structures of epithelial layer in gut $A$. salina in different stages using means and standard error (SE) of cell score system assessing histological effects of TBTCl in the epithelial cell structures of nauplii, juveniles, and adult stages and the scoring methods for pathological lesions were [0: Normal (0), 1: Mild $(<25), 2$ : Moderate $(<50), 3$ : Severe $(<75)$, 4: Very severe (above 75$)$ based on the type of epithelial cell damage structures]. Statistical analysis was performed using the nonparametric Kruskal-Wallis test, chi-square $p<0.05$. Differences were considered significant at $p<0.05$ to find different effects between the pathological lesions of epithelial layer in gut $A$. salina and increasing the concentration of TBTCl. Tissue sections were scored on a grade of 0 to 4 . Analysis software was used to analyze the photomicrographs (Amer, 2014; Coolidge et al., 1979).

\section{Results}

Effects of TBTCl on the gut epithelial layer of nauplii stage

The mean lesion scores for 24 hours after exposure of the nauplii to different concentrations of TBTCl 
are depicted in Table 1. The predominant lesions were epithelial cell necrosis, degeneration, cell loss, disruption, and piknosis, and the exposed groups were significantly different, and the results showed according to non-parametric Kruskal-Wallis test, chi-square $p$ $<0.05$ a significant between the control and different concentrations. At the concentration of 200 ng. $\mathrm{L}^{-1}$ exposure, the epithelial cell necrosis was seen to have the highest lesion score $2.00 \pm 0.29$ compared to the other lesions and the least was epithelial cell loss and disruption, which had scores of $0.50 \pm 0.09$ each. At the concentration of $300 \mathrm{ng} . \mathrm{L}^{-1}$ of TBTCl, predominant lesions were epithelial cell necrosis and piknosis with scores of $1.75 \pm 0.15$ each while the least lesion scores $0.5 \pm 0.09$ were epithelial cell loss. At the concentration of $350 \mathrm{ng} . \mathrm{L}^{-1}$, epithelial cell degeneration and disruption recorded the highest scores of $1.33 \pm 0.06$ each while the least lesion under this concentration was epithelial cell necrosis. At concentrations of $400 \mathrm{ng} . \mathrm{L}^{-1}$ and 450 ng. $\mathrm{L}^{-1}$, the lesion scores ranged from $1.5 \pm 0.29$ in epithelial cell necrosis in $400 \mathrm{ng} . \mathrm{L}^{-1}$ to $0.5 \pm 0.09$. However, at $500 \mathrm{ng} . \mathrm{L}^{-1}$ concentration, the highest lesion scores were recorded in epithelial cell disruption $2.5 \pm$ 0.99 and epithelial cell degeneration $2.25 \pm 1.25$. Based on the lesion scores of the tissues of the nauplii 24 hours after exposure, the highest lesion score of 2.5 and 2.25 was found in the concentration of $500 \mathrm{ng} . \mathrm{L}^{-1}$, which had the highest total score of 8 . This was followed by lesions associated with TBTCl at a concentration of $300 \mathrm{ng} . \mathrm{L}^{-1}$, which had a total score of 6.17, and the least lesion score was associated with $400 \mathrm{ng} . \mathrm{L}^{-1}$ concentration, which had a total score of 4.01. The results show lesion under different concentrations in Figure 1.

Effects tributyltin chloride (TBTCl) on the gut epithelium layer of juveniles stage

The mean lesion scores for 24 hours post-exposure of the juveniles to different concentrations of TBTCl are presented in Table 2. The predominant lesions associated with different concentrations of TBTCl were epithelial cell necrosis, degeneration, cell loss, disruption, and piknosis. For the juveniles, the concentrations of TBTCl were 50, 100, 150, 200 and $250 \mathrm{ng} . \mathrm{L}^{-1}$. The results showed according to the nonparametric Kruskal-Wallis test, chi-square $p<0.05$ a significant between the epithelium layer in juveniles gut and TBTCl different groups. In this group, lesion scores associated with TBTCl at 50 ng.L. ${ }^{-1}, 100$ ng. $\mathrm{L}^{-1}$, and 200 ng. $\mathrm{L}^{-1}$ were not significantly different from each other. However, at the concentration of 150 ng. $\mathrm{L}^{-1}$, the total lesion scores were 11.33 , which was significantly higher compared to the other concentrations, and the least total score (8.5) was obtained from TBTCl at the concentration of $250 \mathrm{ng}$. $\mathrm{L}^{-1}$. Epithelial cell disruptions have the highest lesion scores compared to other lesions. Generally, the lesion scores in the juveniles were significantly higher compared to those from the nauplii. The lesions for different concentrations are provided in Figure 2.

\section{Effects tributyltin chloride (TBTCl) on the gut epithelial layer in adult stage}

The mean lesion scores for 24 hours post-exposure of adults $A$. salina to different concentrations of TBTCl are shown in Table 3. The concentrations of the TBTCl in this group were $25,50,100,200$, and 300 ng. $\mathrm{L}^{-1}$. The predominant lesions were similar to those of the nauplii and juveniles. The results showed according to the nonparametric Kruskal-Wallis test, chi-square $p<0.05$ a significant difference between the groups of TBTCl and gut epithelial layer in adult $A$. salina. Lesions with the highest scores were epithelial cell necrosis and degeneration, and the least was epithelial cell disruption. The least total lesion scores of 8.1 were associated with TBTCl at the concentration of $200 \mathrm{ng} . \mathrm{L}^{-1}$ followed by TBTCl at 25 ng. $\mathrm{L}^{-1}$, which had a total lesion score of 9.2. However, lesion scores at the concentration of 50, 100, and $300 \mathrm{ng} . \mathrm{L}^{-1}$ were not significantly different from each other and were the highest in this group. The generality of the lesion scores showed that the adult is relatively more susceptible to the effects of TBTCl compared to the juvenile and was more susceptible compared to the nauplii. The adult results show lesion under different concentrations in Figure 3.

Table 1. The means and the SE of cell scores from the cell scoring system assessing histological effects of (TBTCl) in epithelial cell structures of nauplii $A$. salina tissues [No. of sample 5].

\begin{tabular}{ccccccc}
\hline TBTCI (ng.L ${ }^{-1}$ ) & $\begin{array}{c}\text { Epithelium cell } \\
\text { necrosis }\end{array}$ & $\begin{array}{c}\text { Epithelium cell } \\
\text { degeneration }\end{array}$ & $\begin{array}{c}\text { Epithelium cell } \\
\text { loss }\end{array}$ & $\begin{array}{c}\text { Epithelium cell } \\
\text { disruption }\end{array}$ & $\begin{array}{c}\text { Nucleus } \\
\text { piknosis }\end{array}$ & Total \\
\hline 0 & $0.00 \pm 0.00$ & $0.00 \pm 0.00$ & $0.00 \pm 0.00$ & $0.00 \pm 0.00$ & $0.00 \pm 0.00$ & 0.00 \\
200 & $2.00 \pm 0.29$ & $1.75 \pm 0.15$ & $0.50 \pm 0.09$ & $0.50 \pm 0.09$ & $1.00 \pm 0.19$ & 5.75 \\
300 & $1.75 \pm 0.15$ & $1.50 \pm 0.29$ & $0.50 \pm 0.09$ & $0.67 \pm 0.33$ & $1.75 \pm 0.15$ & 6.17 \\
350 & $0.50 \pm 0.09$ & $1.33 \pm 0.06$ & $1.00 \pm 0.19$ & $1.33 \pm 0.06$ & $0.67 \pm 0.33$ & 4.83 \\
400 & $1.50 \pm 0.29$ & $0.67 \pm 0.33$ & $0.50 \pm 0.09$ & $0.67 \pm 0.33$ & $0.67 \pm 0.33$ & 4.01 \\
450 & $1.00 \pm 0.19$ & $1.00 \pm 0.19$ & $1.00 \pm 0.19$ & $1.00 \pm 0.19$ & $1.00 \pm 0.19$ & 5.00 \\
\hline 500 & $2.00 \pm 0.29$ & $2.25 \pm 1.25$ & $1.00 \pm 0.19$ & $2.50 \pm 0.99$ & $1.25 \pm 0.24$ & 8.00 \\
\hline
\end{tabular}

Scoring Methods: 0: Normal (0); 1: Mild (<25); 2: Moderate $(<50)$; 3: Severe $(<75)$; 4: very severe (above75). Remark: All data are presented with \pm SE. 

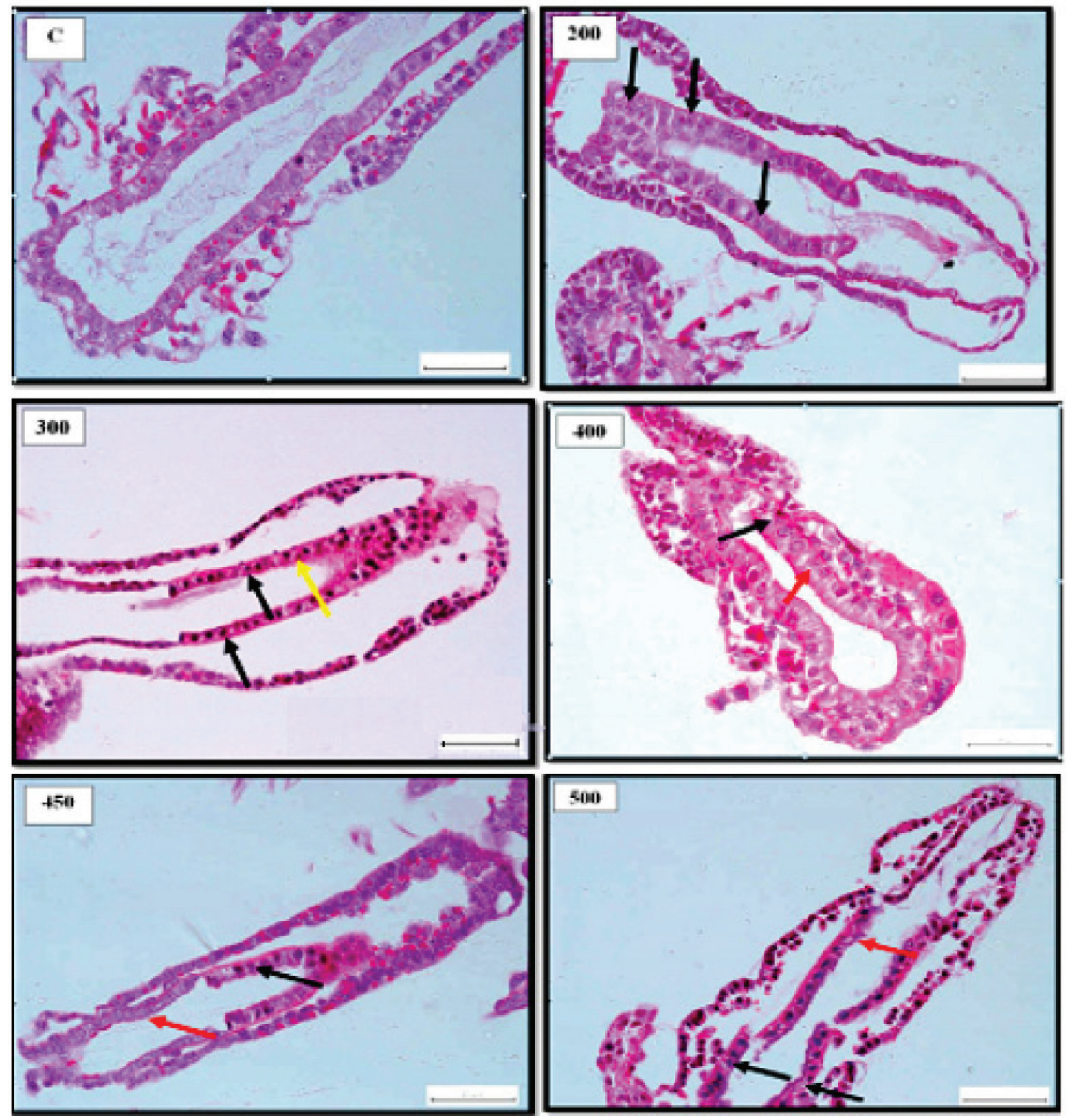

Fig. 1. Representative photomicrograph of gut section of nauplii showing normal histologically structures of gut epithelial cells of control [C]. 200 ng.L $\mathrm{L}^{-1}$ showing histologically changes following 24 hours. exposure to $\mathrm{TBTCl}$ at with indications of nucleus piknosis (black arrows). 300 ng. $\mathrm{L}^{-1}$ showing indications of nucleus piknosis (black arrows) and epithelial cell disruption (yellow arrow). $400 \mathrm{ng} . \mathrm{L}^{-1}$ showing indications of epithelial cell necrosis (black arrow), nucleus piknosis (red arrow) and epithelial cell disruption (yellow arrow). $450 \mathrm{ng} . \mathrm{L}^{-1}$ showing histological indications of disrupted gut epithelial cell lining (black arrow) and nucleus piknosis (red arrow) and $500 \mathrm{ng} . \mathrm{L}^{-1}$ showing histological changes following indications of disrupted epithelial cell lining (black arrows), epithelial cell loss (red arrow) and necrosis (yellow arrow). [H and E - 40× ].

Table 2. The means and the SE of cell scores from the cell scoring system assessing histological effects of tributyltin chloride (TBTCl) in the epithelial cell structures of juveniles A. salina tissues [No. of sample 5].

\begin{tabular}{cccccccc}
\hline TBTCI (ng. $\mathbf{L}^{-1}$ ) & $\begin{array}{c}\text { Epithelium cell } \\
\text { necrosis }\end{array}$ & $\begin{array}{c}\text { Epithelium cell } \\
\text { degeneration }\end{array}$ & $\begin{array}{c}\text { Epithelium cell } \\
\text { loss }\end{array}$ & $\begin{array}{c}\text { Epithelium cell } \\
\text { disruption }\end{array}$ & $\begin{array}{c}\text { Nucleus } \\
\text { piknosis }\end{array}$ & Total mean \\
\hline 0 & $0.00 \pm 0.00$ & $0.00 \pm 0.00$ & $0.00 \pm 0.00$ & $0.00 \pm 0.00$ & $0.00 \pm 0.00$ & 0.00 \\
50 & $2.00 \pm 0.29$ & $2.00 \pm 0.29$ & $2.00 \pm 0.29$ & $2.00 \pm 0.29$ & $1.00 \pm 0.19$ & 9.00 \\
100 & $2.00 \pm 0.29$ & $2.00 \pm 0.29$ & $2.00 \pm 0.29$ & $3.00 \pm 0.99$ & $1.00 \pm 0.19$ & 10.00 \\
150 & $2.33 \pm 0.67$ & $2.67 \pm 0.33$ & $2.00 \pm 0.29$ & $3.00 \pm 0.99$ & $1.33 \pm 0.67$ & 11.33 \\
\hline 200 & $2.00 \pm 0.29$ & $2.33 \pm 0.67$ & $2.33 \pm 0.67$ & $2.00 \pm 0.29$ & $2.00 \pm 0.29$ & 10.66 \\
250 & $2.00 \pm 0.29$ & $2.00 \pm 0.29$ & $1.50 \pm 0.29$ & $2.50 \pm 0.99$ & $0.50 \pm 0.09$ & 8.50 \\
\hline
\end{tabular}

Scoring Methods: 0: Normal (0); 1: Mild $(<25) ; 2$ : Moderate $(<50)$; 3: Severe $(<75)$; 4: very severe (above75). Remark: All data are presented with \pm SE. 


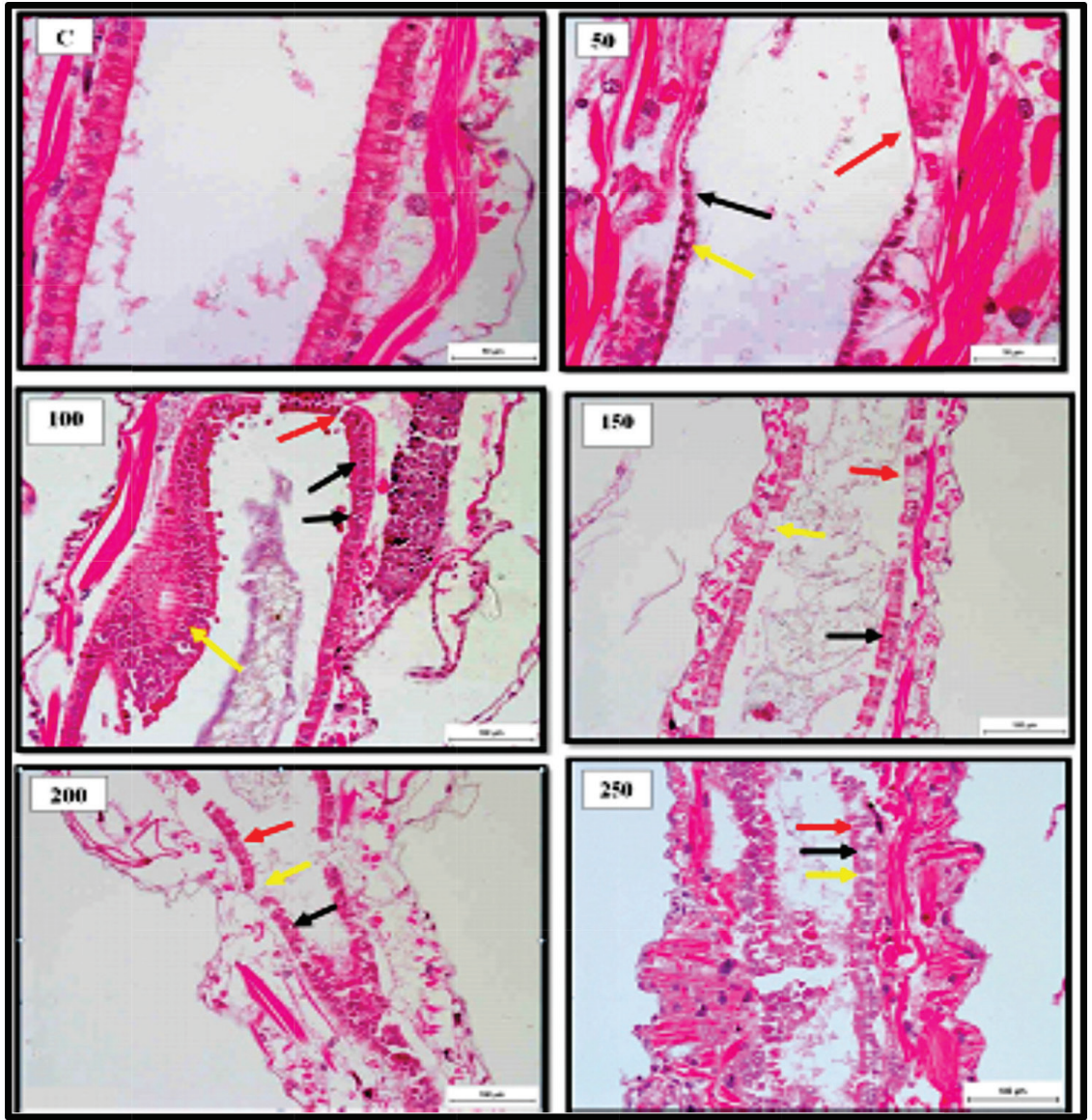

Fig. 2. Representative photomicrograph of mid gut section of the juveniles with indications of normal histological structure of gut epithelial cells of the control [C]. 50 ng.L $\mathrm{L}^{-1}$ showing histological changes following 24 hours. exposure to TBTCl concentrated with indications of disrupted epithelial cell (black arrow), epithelial cell loss (red arrow) and necrosis (yellow arrows). $100 \mathrm{ng} . \mathrm{L}^{-1}$ showing degenerating epithelial cells (yellow arrow) with disrupted epithelial cells floating in the gut lumen (black arrows) and necrosis (red arrow). 150 ng. $\mathrm{L}^{-1}$ showing histological changes of epithelial cell loss (black arrows). 200 ng.L - $^{-1}$ showing histological changes of the disrupted epithelial cell (black arrow), epithelial cell loss (red arrow) and necrosis (yellow arrows). 250 ng.L. ${ }^{-1}$ showing histological of the disrupted epithelial cell (black arrow), epithelial cell loss (red arrow) and necrosis (yellow arrows). [H and $\mathrm{E}-40 \times]$.

Table 3. Mean and the SE of cell scores from the cell scoring system assessing histological effects of tributyltin chloride (TBTCl) in the epithelial cell structures of adult $A$. salina tissues [No. of sample 5].

\begin{tabular}{|c|c|c|c|c|c|c|}
\hline TBTCI (ng.L L $\left.^{-1}\right)$ & $\begin{array}{c}\text { Epithelium cell } \\
\text { necrosis }\end{array}$ & $\begin{array}{c}\text { Epithelium cell } \\
\text { degeneration }\end{array}$ & $\begin{array}{c}\text { Epithelium cell } \\
\text { loss }\end{array}$ & $\begin{array}{l}\text { Epithelium cell } \\
\text { disruption }\end{array}$ & $\begin{array}{l}\text { Nucleus } \\
\text { piknosis }\end{array}$ & Total mean \\
\hline 0 & $0.00 \pm 0.00$ & $0.00 \pm 0.00$ & $0.00 \pm 0.00$ & $0.00 \pm 0.00$ & $0.00 \pm 0.00$ & 0.00 \\
\hline 25 & $2.00 \pm 0.29$ & $2.40 \pm 1.00$ & $1.80 \pm 0.50$ & $2.00 \pm 0.29$ & $1.0 \pm 0.19$ & 9.20 \\
\hline 50 & $3.00 \pm 0.99$ & $2.80 \pm 0.60$ & $1.50 \pm 0.29$ & $1.30 \pm 0.10$ & $1.6 \pm 0.19$ & 10.20 \\
\hline 100 & $2.80 \pm 0.60$ & $2.80 \pm 0.60$ & $2.00 \pm 0.29$ & $1.60 \pm 0.19$ & $1.4 \pm 0.10$ & 10.60 \\
\hline 200 & $2.40 \pm 1.00$ & $2.40 \pm 1.21$ & $1.00 \pm 0.19$ & $1.00 \pm 0.19$ & $1.3 \pm 0.10$ & 8.10 \\
\hline 300 & $2.80 \pm 0.60$ & $2.80 \pm 0.60$ & $1.30 \pm 0.10$ & $1.30 \pm 0.10$ & $2.2 \pm 0.90$ & 10.40 \\
\hline
\end{tabular}

Scoring Methods: 0: Normal (0); 1: Mild $(<25) ; 2$ : Moderate $(<50) ; 3$ : Severe $(<75)$; 4: very severe (above 75). Remark: All data are presented with \pm SE. 


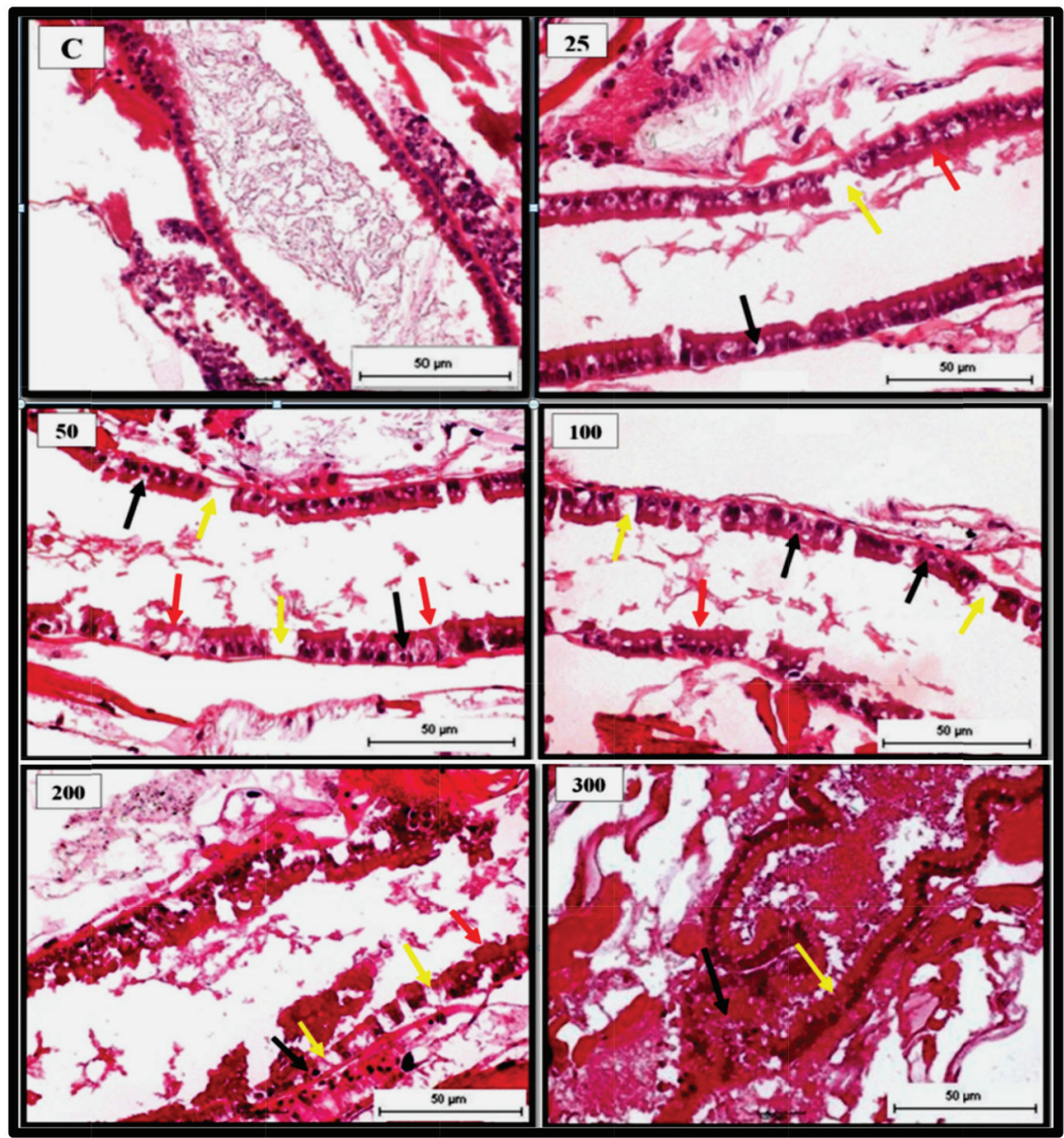

Fig. 3. Representative photomicrograph of mid gut section of the adult with indications of normal histological structure of gut epithelial cells of the control [C]. 25 ng. $\mathrm{L}^{-1}$ showing histological changes following 24 hours. exposure to TBTCl concentrated with indications of epithelial cell loss (yellow arrow), piknosis (black arrow) and necrosis (red arrow). $50 \mathrm{ng}$. $\mathrm{L}^{-1}$ showing histological changes of the disrupted epithelial cell lining (red arrow), epithelial cell loss (yellow arrow) and piknosis (black arrow). 100 ng.L $\mathrm{L}^{-1}$ showing histological of the disrupted epithelial cell lining (red arrow), epithelial cell loss (yellow arrow) and necrosis (black arrow). 200 ng. $\mathrm{L}^{-1}$ showing histological changes of the disrupted epithelial cell lining (red arrow), epithelial cell loss (yellow arrow) and necrosis (black arrow), and 300 ng.. $\mathrm{L}^{-1}$ showing histological changes of disrupted epithelial cell line (yellow arrow) and haemocytic inflammation (black arrow) at the basal layer of the cuticular epithelial linings and gut epithelial lumen filled with cellular debris (red arrow) [H and E - 40× ].

\section{Discussion}

Owing to the proven effectiveness of TBTCl-based antifouling paints, they were popular in the 1960s. However, some years later, TBTCl was found to have harmful effects on aquatic organisms (De Castro et al., 2012). Since 1991, measurements of TBTCl concentration in United States waters have indicated no risk of acute toxicity to aquatic organisms, hence the risk of chronic toxicity was considered as low levels as at 1996 (Cardwell et al., 1999; De Castro et al., 2012). Unfortunately, only a limited number of studies have demonstrated significant histological changes and toxicity of TBTCl on marine crustacean species (Alyürük and Çavaş, 2013; DeLorenzo et al., 2001; Rao et al., 2007). This study reports pathological changes in epithelial cell gut of $A$. salina at different developmental stages for 24 hours post-exposure to different concentrations of TBTCl.

The global still affected by organotin compounds in addition to their known toxicity potential has led to increasing concern on the environmental impact of these pollutants and their effects on the ecosystem for years to come (Furdek et al., 2012). In recent years, the use of organotins as antifouling agents has been 
shown to significant pollutants in aquatic ecosystems (Ranilalitha et al., 2014). The mortality recorded in all the three stages of $A$. salina investigated following exposure to TBTCl is associated with the toxicity of TBTCl, which has been similarly reported in previous related studies to be toxic to Artemia sp (Abushaala et al., 2017; Kungolos et al., 2001).

The gut of $A$. salina is a simplified straight tube made of a single layer of epithelial cells, which has a pair of small globular diverticula in the head region. Additionally present in the gut tube is a thin peritrophic membrane (Croghan, 1958). In this study, the gut epithelial cells were most affected with lesions such as epithelial cell necrosis, nucleus piknosis, degeneration, and epithelial cell loss. Since it has been established that shrimps ingest some of its medium both in the presence or absence of particles (Croghan, 1958), and in this case, the medium was contaminated with TBTCl, it, therefore, follows that the pathological lesions observed in the gut of the brine shrimps were a result of the brine shrimps ingesting the toxic water that was contaminated with different concentrations of TBTCl. The presence of these lesions is indications of the toxicity induced by TBTCl pollution. Even though studies investigating histopathological changes in the gut epithelium of the brine shrimps are scanty or not available, the histopathological changes such as the epithelial cell necrosis, nucleus piknosis, epithelial cell degeneration, and epithelial cell loss could be associated with TBTCl toxicity. However, the exact mechanisms through which TBTCl toxicity causes these lesions may require further studies.

Like many other aquatic organisms, the brine shrimps, A. salina also accumulate trace elements that are subsequently transferred to higher levels in the food chain; hence it is essential to determine the relationship between the brine shrimps and its tolerance range for various water pollutants. In this study, significant differences were seen in the level of resistance to TBTCl concentrations by different stages of the brine shrimps. The nauplii were observed to be more resistant to TBTCl contamination compared to the juveniles and the adults' brine shrimps. This was seen in the differences recorded in lesion scores where the nauplii scored less compared to the juveniles and the adults. This finding corroborates with the findings documented in other related studies (Sánchez et al., 2016; Sorgeloos et al., 1978) who reported that brine shrimps at the resistance of newly hatched larvae of brine shrimps were high and relatively inconsistent, just as observed in this study. The reason for this difference in resistance to TBTCl could be associated with the feeding habit of the brine shrimp. Since the brine shrimps have been documented to be filter feeders (Croghan, 1958), ingesting the surrounding water together with food particles, the juvenile and the adults probably ingested more of the TBTCl through feeding, unlike the nauplii which fed less, thereby leading to less pathological lesions.

\section{Conclusion}

This work revealed for the first time not only the toxicity of TBTCl to the brine shrimps but further the pathological changes such as epithelial cell necrosis, degeneration, disruption, cell loss, and nucleus piknosis that were associated with the gut epithelial cells of the brine shrimps $A$. salina exposed to TBTCl contaminated water. Based on the results of this work, it is clear that toxicity of TBTCl to the brine shrimps was associated with pathological lesions as stated above, which cause mortality following exposure. This study also noted that the nauplii were more resistant to TBTCl toxicity compared to the juveniles and the adult Artemia. This study reconfirmed the suitability of the brine shrimp Artemia sp for assessing the marine toxicity profile of any toxicant with simple and reproducible results.

\section{Acknowledgments}

The author is grateful to Department of Biology, Faculty of Science, and Department of Histology, Faculty of Veterinary, University Putra Malaysia for providing facilities and equipment for this investigation.

\section{Conflict of interest}

None

Funding

None

\section{References}

Abushaala, N.M., Zulkifli, S.Z., Ismail, A., Azmai, M.N.A. and Mohamat-Yusuff, F. 2015. Selected morphological changes in Nauplii of Brine Shrimp (Artemia salina) after Tributyltin Chloride (TBTCL) Exposure. World Appl. Sci. J. 33(8), 1334-1340.

Abushaala, N.M., Zulkifli, S.Z., Ismail, A., Azmai, M.N.A., Mohamat-Yusuff, F. and Omar, H. 2017. Effects of tributyltin chloride (TBTCl) antifouliong biocide on adult males and females of brine shrimp (Artemia salina). Int. J. Biol. Res. 5(1), 30-35.

Alyürük, H. and Çavaş, L. 2013. Toxicities of diuron and irgarol on the hatchability and early stage development of Artemia salina. Turk. J. Biol. $37(2), 151-157$.

Amer, A.A.A. 2014. The effect of cadmium chloride on the biology of gammarus pulex (Crustacea: Amphipoda), PhD Thesis, University of Exeter, UK.

Cardwell, R., Keithly, J. and Simmonds, J. 1999. Tributyltin in US market-bought seafood and assessment of human health risks. Human Ecol. Risk Assess.: Int. J. 5(2), 317-335.

Coolidge, B.J., Sanders, B.J. and Howard, R.M. 1979. Animal histology procedures: US Department of Health, Education, and Welfare, Public Health Service, National Institutes of Health.

Costa, M., Zamprogno, G., Pedruzzi, F., Dalbem, G. and Tognella, M. 2013. Assessing the continuous impact of tributyltin from antifouling paints in a Brazilian Mangrove area using intersex in Littoraria 
angulifera (Lamarck, 1822) as Biomarker. Int. J. Ocean. 2013, 8. Available via http://dx.doi. org/10.1155/2013/769415

Couch, J.A. 1977. Ultrastructural study of lesions in gills of a marine shrimp exposed to cadmium 1. J. Invert. Pathol. 29(3), 267-288.

Croghan, P. 1958. The mechanism of osmotic regulation in Artemia salina (L.): the physiology of the branchiae. J. Exp. Biol. 35(1), 234-242.

Cuypers, A., Plusquin, M., Remans, T., Jozefczak, M., Keunen, E., Gielen, H. and Artois, T.J. 2010. Cadmium stress: an oxidative challenge. Biometals. 23(5), 927-940.

De Castro, Í.B., Perina, F.C. and Fillmann, G. 2012. Organotin contamination in South American coastal areas. Environ. Monit. Assess. 184(3), 1781-1799.

DeLorenzo, M.E., Scott, G.I. and Ross, P.E. 2001. Toxicity of pesticides to aquatic microorganisms: a review. Environ. Toxcoli. Chem. 20(1), 84-98.

Frías-Espericueta, M.G., Abad-Rosales, S., NevárezVelázquez, A.C., Osuna-López, I., Páez-Osuna, F., Lozano-Olvera, R. and Voltolina, D. 2008. Histological effects of a combination of heavy metals on Pacific white shrimp Litopenaeus vannamei juveniles. Aquat. Toxicol. 89(3), 152157.

Furdek, M., Vahčič, M., Ščančar, J., Milačič, R., Kniewald, G. and Mikac, N. 2012. Organotin compounds in seawater and Mytilus galloprovincialis mussels along the Croatian Adriatic Coast. Mar. Pollu. Bull. 64(2), 189-199.

Gallo, A. and Tosti, E. 2015. Antifouling compounds endangering marine invertebrates reproduction. J. Mar. Sci.: Res. Develop. 5(1), 1000e133.

Gibbs, P., Pascoe, P. and Burt, G. 1988. Sex change in the female dog-whelk, Nucella lapillus, induced by tributyltin from antifouling paints. J. Mar. Biol. Assoc. UK. 68(4), 715-731.

Griffiths, P. 1980. Morphological and ultrastructural effects of sublethal cadmium poisoning on Daphnia. Environ. Res. 22(2), 277-284.

Kungolos, A., Hadjispyrou, S., Samaras, P., Petala, M., Tsiridis, V., Aravossis, K. and Sakellaropoulos, G. 2001. Assessment of toxicity and bioaccumulation of organotin compounds. Paper presented at the International Conference Environmental Science.

Li, Z.H., Li, P. and Shi, Z.C. 2015. Chronic exposure to tributyltin induces brain functional damage in juvenile common carp (Cyprinus carpio). PLoS One. 10(4), e0123091.

Meador, J.P. 1997. Comparative toxicokinetics of tributyltin in five marine species and its utility in predicting bioaccumulation and acute toxicity. Aqua. Toxicol. 37(4), 307-326.

Mee, L.D. and Fowler, S.W. 1991. Special issue on organotin. Mar. Environ. Res. 32(1), 1-5.
Mitra, S., Siddiqui, W.A. and Khandelwal, S. 2015. Differential susceptibility of brain regions to tributyltin chloride toxicity. Environ. Toxicol. 30(12), 1393-1405.

Nunes, B.S., Carvalho, F.D., Guilhermino, L.M. and Van Stappen, G. 2006. Use of the genus Artemia in ecotoxicity testing. Environ. Pollu. 144(2), 453462.

Pack, E.C., Kim, C.H., Lee, S.H., Lim, C.H., Sung, D.G., Kim, M.H. and Choi, D.W. 2014. Effects of environmental temperature change on mercury absorption in aquatic organisms with respect to climate warming. J. Toxicol. Environ. Heal Part A. 77(22-24), 1477-1490.

Panagoula, B., Panayiota, M. and IliopoulouGeorgudaki, J. 2002. Acute toxicity of TBT and Irgarol in Artemia salina. Int. J. Toxicol. 21(3), 231-233.

Papathanassiou, E. and King, P. 1986. Ultrastructural changes in hepatopancreatic cells of the prawn Palaemon serratus induced by exposure to acutely toxic cadmium concentrations. Dis. Aquat. Org. 2(1), 39-47.

Peranandam, R., Palanisamy, I. and Natesan, M. 2013. Bioaccumulation of tributyltin and its impact on spermatogenesis in mud crab Scylla serrata (Forskal). Turk. J. Biol. 37(3), 296-304.

Ranilalitha, P., Sukumaran, M., and Raveendran, S. 2014. Effect of TBTCL on phosphatases activity in estuarine edible clam, Anadara rhombea born (Bivalvia: Mollusca). Int. J. Pure Appl. Zool. 2, 315-320.

Rao, J.V., Kavitha, P., Jakka, N., Sridhar, V. and Usman, P. 2007. Toxicity of organophosphates on morphology and locomotor behavior in brine shrimp, Artemia salina. Arch. Environ. Cont. Toxicol. 53(2), 227-232.

Sánchez, M.I, Petit, C., Martínez-Haro, M., Taggart, M.A. and Green, A.J. 2016. May arsenic pollution contribute to limiting Artemia franciscana invasion in southern Spain: PeerJ. 4:e1703. Available via https://doi.org/10.7717/peerj.1703

Soegianto, A., Charmantier-Daures, M., Trilles, J.P. and Charmantier, G. 1999. Impact of copper on the structure of gills and epipodites of the shrimp Penaeus japonicus (Decapoda). J. Crust. Biol. 19(2), 209-223.

Sorgeloos, P., Remiche-Van Der Wielen, C. and Persoone, G. 1978. The use of Artemia nauplii for toxicity tests a critical analysis. Ecotoxicol. Environ. Saf. 2(3-4), 249-255.

Sreeram, M.P. and Menon, N. 2005. Histopathological changes in the hepatopancreas of the penaeid shrimp Metapenaeus dobsoni exposed to petroleum hydrocarbons. J. Mar. Biol. Assoc. India. 47(2), $160-168$. 
Wu, J.-P., Chen, H.-C. and Huang, D.-J. 2009. Histopathological alterations in gills of white shrimp, Litopenaeus vannamei (Boone) after acute exposure to cadmium and zinc. Bull. Environ. Conta. Toxicol. 82(1), 90-95.

Yamuna, A., Bhavan, P.S. and Geraldine, P. 2009. Ultrastructural observations in gills and hepatopancreas of prawn Macrobrachium malcolmsonii exposed to mercury. J. Environ. Biol. 30(5), 693.
Žnidaršič, N., Štrus, J. and Drobne, D. 2003 Ultrastructural alterations of the hepatopancreas in Porcellio scaber under stress. Environ. Toxicol. Pharmacol. 13(3), 161-174.

Zuo, Z., Wu, T., Lin, M., Zhang, S., Yan, F., Yang, Z. and Wang, C. 2014. Chronic exposure to tributyltin chloride induces pancreatic islet cell apoptosis and disrupts glucose homeostasis in male mice. Environ. Sci. Technol. 48(9), 5179-5186. 